\title{
Catalytic asymmetric aziridination of imines
}

\author{
Peter Wipf* and Michael A. Lyon \\ Department of Chemistry, University of Pittsburgh \\ Pittsburgh, Pennsylvania 15260, U.S.A. \\ E-mail:pwipf@pitt.edu
}

Dedicated to Professor Madeleine M. Joullié on her $80^{\text {th }}$ birthday

\begin{abstract}
Introduction of bulky arene substituents into the 3- and 3'-positions of binaphthol boronates led to a significant improvement of chiral induction in the aziridination of benzylidene benzhydrylamines.
\end{abstract}

Keywords: Aziridines, imine additions, binaphthol ligands, boron Lewis acids, ethyl diazoacetate

\section{Introduction}

Aziridines are important intermediates in organic synthesis. $\mathrm{S}_{\mathrm{N}} 2$ ring opening reactions, for example, result in substituted amines, diamines, amino alcohols, and $\alpha$ - or $\beta$-amino acids. ${ }^{1}$ Aziridines are also important heterocyclic substructures present in a number of interesting biologically active natural products, ${ }^{2}$ as well as therapeutic agents. ${ }^{3}$

Several methods are available for the preparation of enantiomerically enriched aziridines. However, most involve multi-step procedures, employing either optically active starting materials or stoichiometric quantities of a chiral auxiliary. ${ }^{1,4}$ Direct approaches to aziridines involve the cycloaddition of a nitrene fragment to an olefin, or a carbene to an imine. The latter approach has been studied by a number of groups. Most noteworthy are efforts by Evans, ${ }^{5}$ Jacobsen, ${ }^{6}$ and Scott $^{7}$ towards the development of an efficient catalytic asymmetric version of a nitrene transfer from $\mathrm{N}$-(p-toluenesulfonyl)imino]phenyliodinane ( $\mathrm{PhI}=\mathrm{NTs}$ ) with a variety of chiral copper Lewis acids. Katsuki and Nishikori also showed that manganese salens were excellent catalytic promotors of the enantioselective aziridination of a series of styrene derivatives in very high yields and enantioselectivities. ${ }^{8}$ Aggarwal reported the catalytic asymmetric aziridination of imines with in situ generated diazo compounds as carbene sources in the presence of chiral sulfides. ${ }^{9}$ The contributions of Wulff and co-workers have been among the most successful to date. The aziridination of a range of benzhydryl imines with ethyl 
diazoacetate, catalyzed by chiral boronates $\mathbf{3}$, gave the optically active heterocycles $\mathbf{4}$ in good yields and excellent enantio- and diastereoselectivies (Scheme 1). ${ }^{10}$ The chiral boronates were derived from the vaulted biaryls VANOL and VAPOL and either $\mathrm{BH}_{3} \bullet$ THF complex or, more efficiently, triphenylborate. In contrast, catalysts derived from linear biaryls such as BINOL and BANOL gave very poor to moderate induction. ${ }^{10,11}$

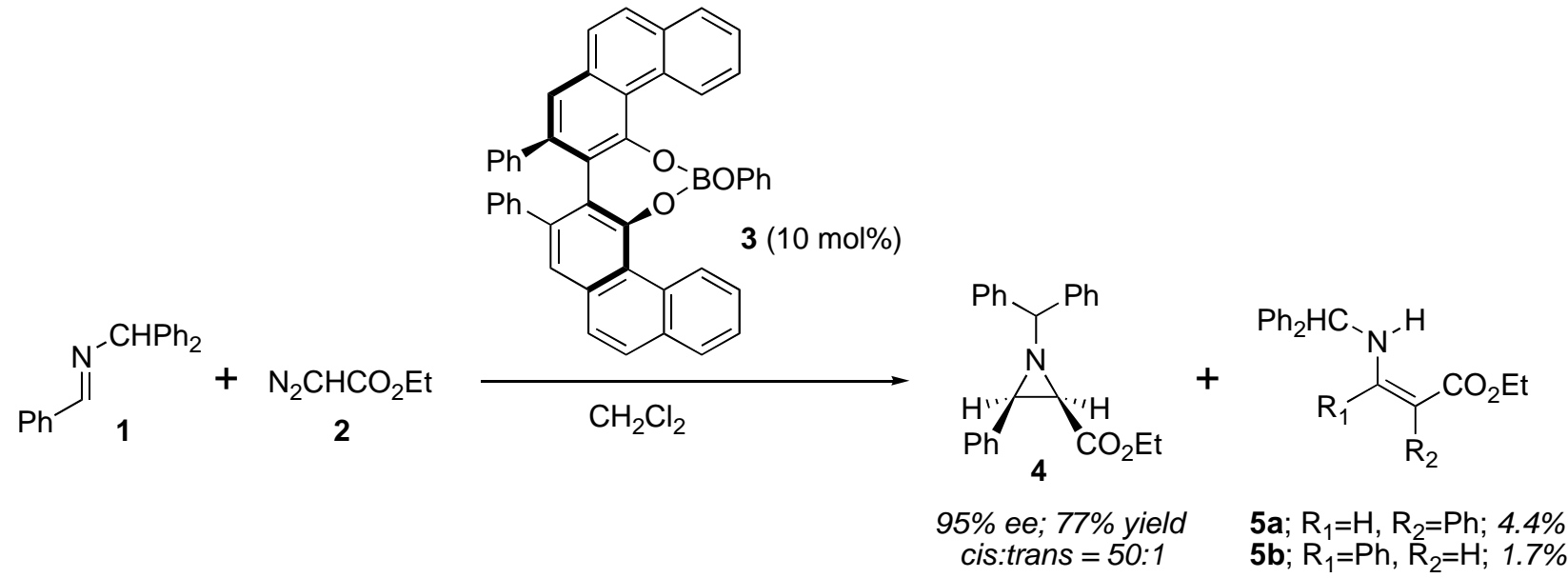

Scheme 1. Catalytic asymmetric imine aziridination with the vaulted biaryl complex $3^{10}$

\section{Results and Discussion}

In the course of our total synthesis of $(+)$-diepoxin $\sigma,{ }^{12}$ we observed good to excellent chiral induction in the asymmetric Diels-Alder reaction between juglone and cyclopentadiene mediated by a boron-binaphthol complex. ${ }^{13}$ This and related reactions were further studied with a series of 3,3'-disubstituted binaphthol ligands, such as 6 and 7 (Figure 1). While binaphthol itself gave poor induction in the chiral aziridine formation, in agreement with the Wulff results, ${ }^{10,11}$ we hypothesized that increasing the steric bulk at the 3,3'-positions would exert improved facial control in carbene additions to imines. ${ }^{14}$ Accordingly, we examined whether the 3,3'-arylated binaphthols $\mathbf{6}-\mathbf{8}$ or the steroidal binaphthols $\mathbf{9}-\mathbf{1 1}^{15,16}$ would demonstrate increased enantioselectivities in imine aziridinations.

Chiral boronate catalysts derived from this set of six ligands $\mathbf{6}$ - $\mathbf{1 1}$ were formed in situ and used to screen the aziridination of $\mathrm{N}$-(4-bromobenzylidene)benzhydrylamine 12 with ethyl diazoacetate (Scheme 2). The results from the screening of the catalysts are presented in Table 1. Generally, the reactions showed excellent diastereoselection for the cis-isomer of the aziridine 13. ${ }^{10 a}$ In addition, there was no evidence of side products such as the enamino ester $\mathbf{5}$ in the ${ }^{1} \mathrm{H}$ NMR spectra of the crude reaction mixtures. The catalysts derived from steroidal-type binaphthol ligands $\mathbf{9}$ - 11, while providing aziridine $\mathbf{1 3}$ in good yields, gave levels of asymmetric induction similar to those observed with the parent binaphthol (entries 1 - 4). ${ }^{10,11}$ However, as expected, increasing the steric effect by introducing bulky substituents in the 3- and 3'-positions 
of the binaphthol scaffold resulted in an increase in the enantioselectivity of the addition. Thus, bisnaphthalene-substituted ligand $\mathbf{8}$ provided aziridine 13 in 58\% ee and 63\% yield (Table 1, entry 5). Ligand 6 provided product in 69\% ee (Table 1, entry 6). The highest levels of asymmetric induction were observed with biaryl ligand 7, which had also yielded the best induction in our asymmetric Diels-Alder process. ${ }^{12}$ Initially, reactions were conducted using methylene chloride (DCM) as solvent, resulting in moderate yields and enantiomeric excess (Table 1, entries 7 and 8). In an effort to improve the yield and enantiomeric excess of the aziridine, we evaluated the effect of variations of solvent, temperature and reaction time. A mixture of methylene chloride and toluene (1:1) led to a significant improvement in both the yield and the enantioselectivity of the process (Table 1, entry 9). The use of (trifluoromethyl)benzene in place of toluene produced the same level of asymmetric induction, but a marked reduction in product yield (Table 1, entry 10). In a mixture of toluene and diethyl ether, aziridine 13 was formed in $80 \%$ ee and $76 \%$ yield after 5 h (Table 1, entry 11). Pure toluene, as well as lower reaction temperatures $\left(0{ }^{\circ} \mathrm{C}, 3 \mathrm{~h}\right.$, followed by r.t., $\left.15 \mathrm{~h}\right)$ led to a reduction in the \%ee (Table 1, entries 12 and 13, respectively). Reactions catalyzed by the chiral boronate derived from ligand 7 in toluene at room temperature, in contrast, gave good yields, and preserved high levels of enantioselectivity (78\% ee) for aziridine 13 (Table 1, entry 14).
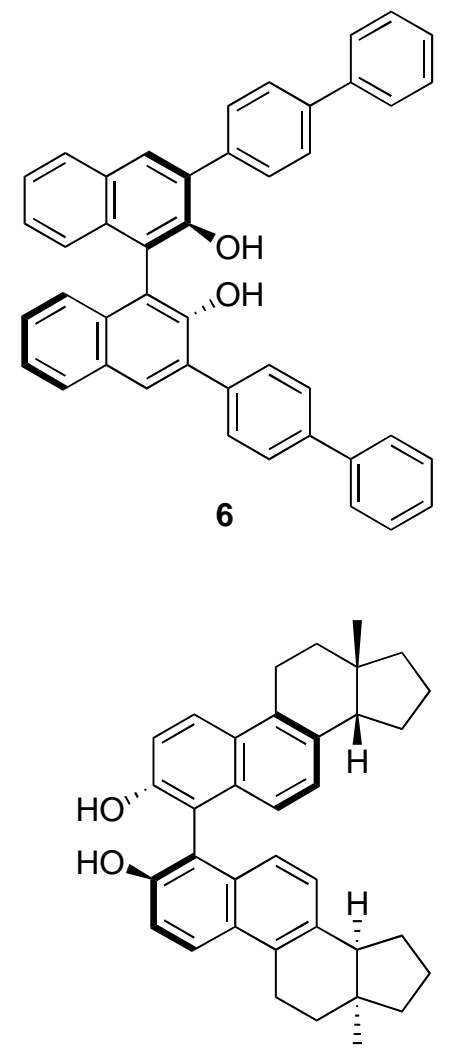

9
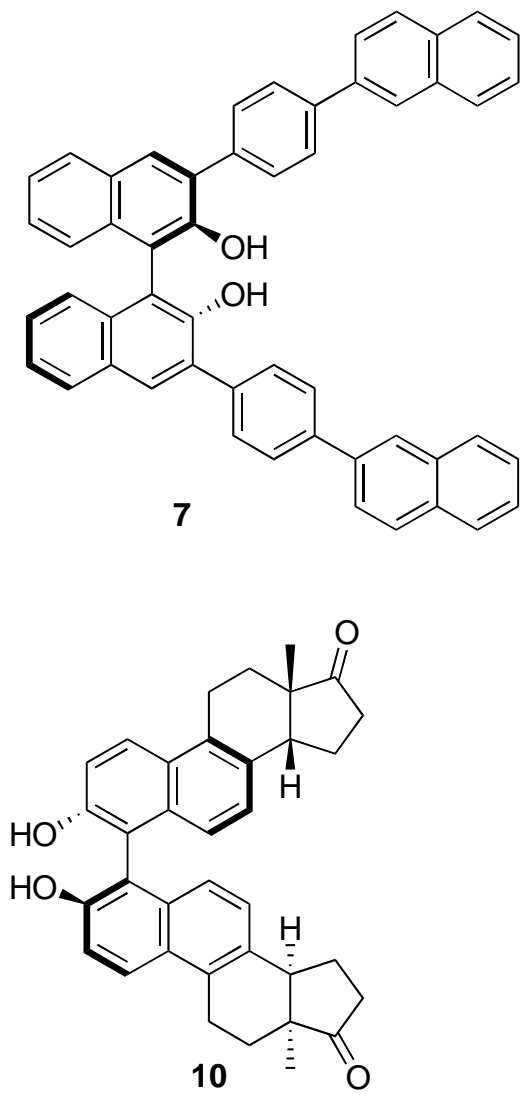<smiles>Oc1c(-c2ccc3ccccc3c2)cc2ccccc2c1-c1c(O)c(-c2ccc3ccccc3c2)cc2ccccc12</smiles>

8

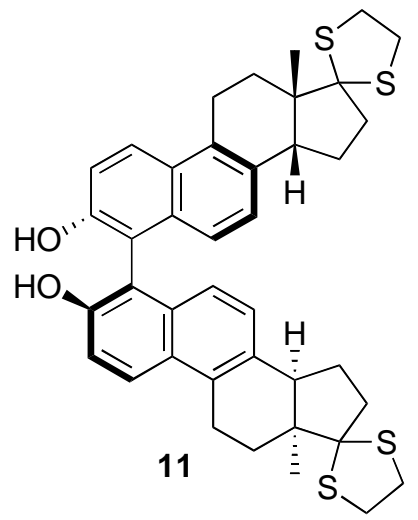

Figure 1. Chiral binaphthol ligands. 

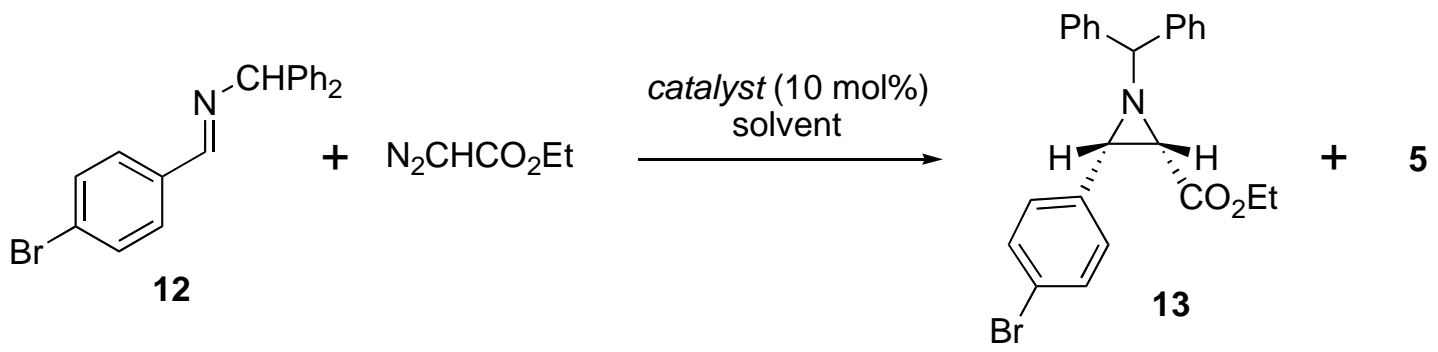

Scheme 2. Catalytic asymmetric imine aziridination with substituted binaphthyl ligands.

Table 1. Catalytic asymmetric imine aziridination with substituted binaphthyl ligands ${ }^{17}$

\begin{tabular}{|c|c|c|c|c|c|}
\hline Entry & Ligand & Solvent & 13 [Yield \%] & 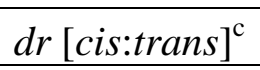 & $e e[\%]^{\mathrm{d}}$ \\
\hline 1 & 9 & Toluene & 66 & 99:1 & 15 \\
\hline 2 & 10 & Toluene & 69 & 99:1 & 28 \\
\hline 3 & 11 & Toluene & 69 & 99:1 & $17^{\mathrm{e}}$ \\
\hline 4 & 11 & Toluene & 50 & 99:1 & $10^{\mathrm{f}}$ \\
\hline 5 & 8 & Toluene & 63 & 99:1 & 58 \\
\hline 6 & 6 & Toluene & 68 & 99:1 & 69 \\
\hline 7 & 7 & DCM & 65 & 99:1 & $58^{g}$ \\
\hline 8 & 7 & DCM & 67 & 99:1 & $64^{\mathrm{h}}$ \\
\hline 9 & 7 & Toluene/DCM & 80 & $99: 1$ & $72^{\mathrm{i}}$ \\
\hline 10 & 7 & $\mathrm{CF}_{3} \mathrm{C}_{6} \mathrm{H}_{5} / \mathrm{DCM}$ & 59 & 99:1 & $70^{\mathrm{j}}$ \\
\hline 11 & 7 & Toluene/ $\mathrm{Et}_{2} \mathrm{O}$ & 76 & 99:1 & $80^{\mathrm{k}}$ \\
\hline 12 & 7 & Toluene & 61 & 99:1 & $62^{1}$ \\
\hline 13 & 7 & Toluene & 81 & 99:1 & $63^{\mathrm{m}}$ \\
\hline 14 & 7 & Toluene & 76 & $99: 1$ & $78^{n}$ \\
\hline
\end{tabular}

${ }^{\mathrm{a}}$ Unless stated otherwise, $0.051 \mathrm{mmol}$ of chiral ligand, $23{ }^{\circ} \mathrm{C}$, 1.1 equiv of ethyl diazoacetate vs imine 12, and $18 \mathrm{~h}$ reaction time were used; imine concentration was maintained at $0.5 \mathrm{M}$ for entries 1-8 and 12-16, and at $0.22 \mathrm{M}$ for entries $9-11$. ${ }^{\mathrm{b}}$ Isolated yields after chromatography on $\mathrm{SiO}_{2}$. ${ }^{\mathrm{c}}$ Determined by ${ }^{1} \mathrm{H}$ NMR analysis of the crude reaction mixture. ${ }^{\mathrm{d}}$ Determined by HPLC analysis (Chiralcel OD); the major enantiomer was assigned in accordance to ref. ${ }^{10 \mathrm{~b}}{ }^{\mathrm{e}}$ Reaction time of $2 \mathrm{~h}$. ${ }^{\mathrm{f}}$ Reaction time of $18 \mathrm{~h} .{ }^{\mathrm{g}}$ Reaction time of $8 \mathrm{~h} .{ }^{\mathrm{h}}$ Reaction time of $18 \mathrm{~h} .{ }^{\mathrm{i}, \mathrm{j}, \mathrm{k}}$ Reaction performed in a 1:1 mixture of solvents. ${ }^{\mathrm{l}}$ Reaction time of $5 \mathrm{~h}$ at $0{ }^{\circ} \mathrm{C}$. ${ }^{\mathrm{m}}$ Reaction temperature of 0 ${ }^{\circ} \mathrm{C}$ for $3 \mathrm{~h}$, then room temperature for $15 \mathrm{~h}$. ${ }^{\mathrm{n}}$ This reaction was repeated several times, in order to ensure reproducibility, with identical $\mathrm{dr}$ and ee ranging from $74-78 \%$.

For a further exploration of the utility of the catalyst derived from ligand 7, benzhydryl imines 1 and 14-16 derived from benzaldehyde, 4-nitrobenzaldehyde, piperonal and 2nitrobenzenesulfonic acid 2-formylphenyl ester, respectively, were used as substrates (Table 2). 
Aziridines 13, ent-4, 17, $,^{11} \mathbf{1 8},{ }^{18}$ and $19^{19}$ were obtained in moderate yields and enantiomeric purities (Table 2, entries 2-5). In contrast, the diastereoselectivity of these insertions was excellent with the exception of benzhydryl imine 16, which resulted in a surprisingly low 60:40 cis:trans isomeric ratio.

Table 2. Catalytic asymmetric aziridination of benzhydryl imines in the presence of ligand 7

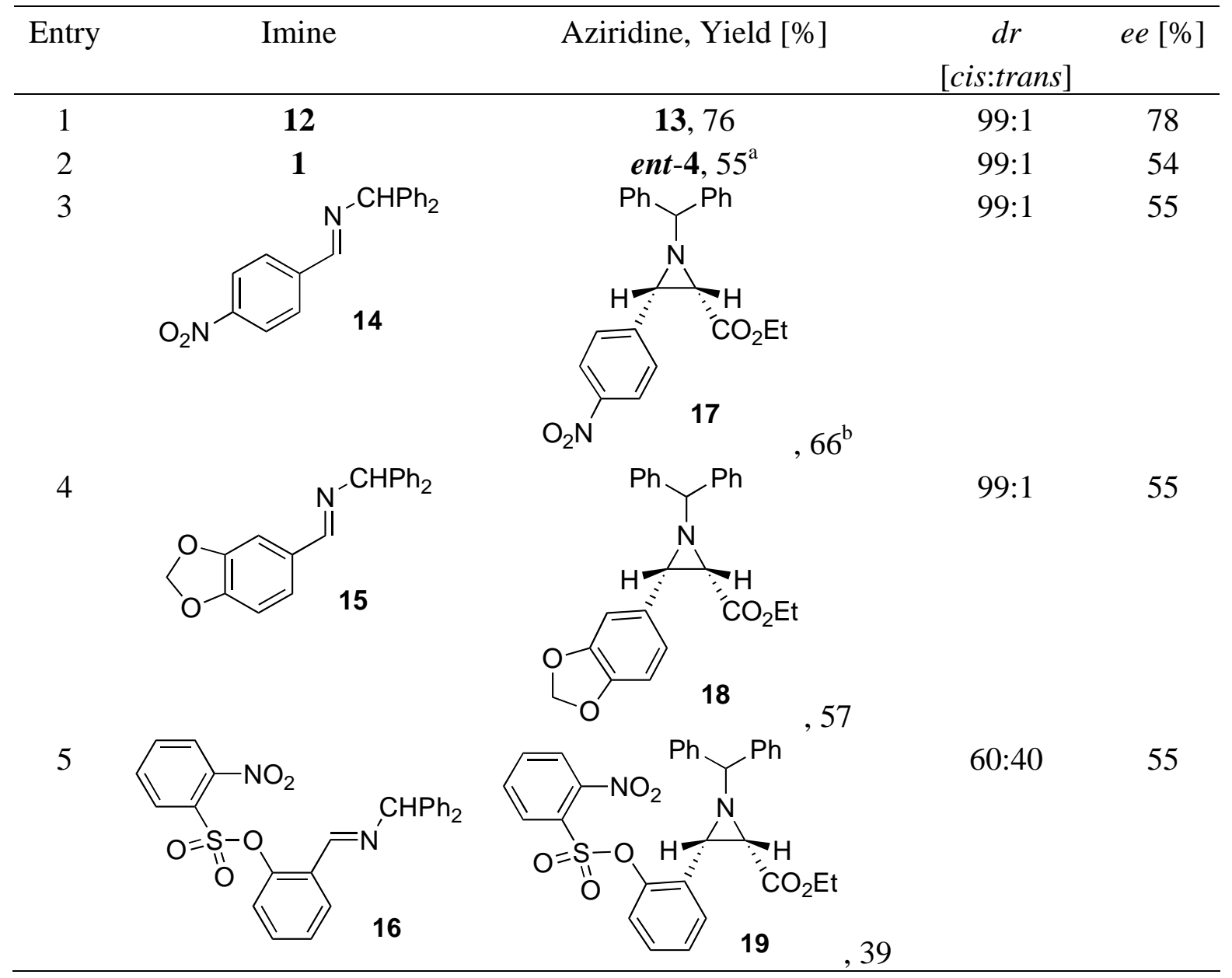

${ }^{a}$ Imine concentration was $0.22 \mathrm{M}$ in toluene, and yield based on recovered imine was $72 \%$. ${ }^{b}$ Reaction was performed in a toluene/ $\mathrm{Et}_{2} \mathrm{O}$ solution $(1: 1)$, with the imine $(0.18 \mathrm{M})$ added by syringe pump over $3 \mathrm{~h}$ to the reaction mixture at $-40{ }^{\circ} \mathrm{C}$, then stirred at room temperature for 15 h.

In conclusion, introduction of bulky arene substituents, in particular the 2-phenylnaphthalene moiety, into the 3- and 3'-positions of the binaphthol scaffold leads to a significant improvement of the level of chiral induction in the aziridination of simple benzhydryl imines. 


\section{Acknowledgment}

This work was supported by the National Institutes of Health (AI-33506). We thank Merck, Roche, and Boehringer-Ingelheim for additional unrestricted support.

\section{References and Notes}

1. (a) McCoull, W.; Davis, F. A. Synthesis 2000, 1347. (b) Cativiela, C.; Diaz-de-Villegas, M. D. Tetrahedron: Asymmetry 1998, 9, 3517. (c) Wipf, P.; Venkatraman, S. Synlett 1997, 1. (d) Tanner, D. Angew. Chem. Int. Ed. Engl. 1994, 33, 599. (e) Li, P.; Forbeck, E. M.; Evans, C. D.; Joullie, M. M. Org. Lett. 2006, 8, 5105. (f) Li, P.; Evans, C. D.; Forbeck, E. M.; Park, H.; Bai, R.; Hamel, E.; Joullie, M. M. Bioorg. Med. Chem. Lett. 2006, 16, 4804.

2. (a) Hodgkinson, T. J.; Shipman, M. Tetrahedron 2001, 57, 4467. (b) Nakao, Y.; Fujita, M.; Warabi, K.; Matsunaga, S.; Fusetani, N. J. Am. Chem. Soc. 2000, 122, 10462. (c) Rajski, S. R.; Williams, R. M. Chem. Rev. 1998, 98, 2723.

3. (a) Skibo, E. B.; Xing, C.; Dorr, R. T. J. Med. Chem. 2001, 44, 3545. (b) Reed, M. W.; Wald, A.; Meyer, R. B. J. Am. Chem. Soc. 1998, 120, 9729. (c) Hargreaves, R. H. J.; Mayalarp, S. P.; Butler, J.; McAdam, S. R.; O'Hare, C. C.; Hartley, J. A. J. Med. Chem. 1997, 40, 357. (d) Otto, H.-H.; Schirmeister, T. Chem. Rev. 1997, 97, 133. (e) Joseph, P. K.; Joullié, M. M. J. Med. Chem. 1964, 7, 801.

4. (a) Kelly, J. W.; Anderson, N. L.; Evans, S. A. J. Org. Chem. 1986, 51, 95. (b) Legters, J.; Thijs, L.; Zwanenburg, B. Tetrahedron Lett. 1989, 30, 4881. (c) Tanner, D.; Somfai, P. Tetrahedron Lett. 1987, 28, 1211. (d) Satoh, T.; Sato, T.; Oohara, T.; Yamakawa, K. J. Org. Chem. 1989, 54, 3973. (e) Ruano, J. L. G.; Fernández, I.; Hamdouchi, C. Tetrahedron Lett. 1995, 36, 295.

5. (a) Evans, D. A.; Faul, M. M.; Bilodeau, M. T.; Anderson, B. A.; Barnes, D. M. J. Am. Chem. Soc. 1993, 115, 5328. (b) Evans, D. A.; Faul, M. M.; Bilodeau, M. T. J. Am. Chem. Soc. 1994, 116, 2742.

6. (a) Shi, M.; Wang, C.-J. Chirality 2002, 14, 412. (b) Li, Z.; Conser, K. R.; Jacobsen, E. N. J. Am. Chem. Soc. 1993, 115, 5326. (c) Li, Z.; Quan, R. W.; Jacobsen, E. N. J. Am. Chem. Soc. 1995, 117, 5889. (d) Quan, R. W.; Li, Z.; Jacobsen, E. N. J. Am. Chem. Soc. 1996, 118, 8156.

7. Sander, C. J.; Gillespie, K. M.; Bell, D.; Scott, P. J. Am. Chem. Soc. 2000, 122, 7132.

8. Nishikori, H.; Katsuki, T. Tetrahedron Lett. 1996, 37, 9245.

9. (a) Aggarwal, V. K.; Alonso, E.; Fang, G.; Ferrara, M.; Hynd, G.; Porcelloni, M. Angew. Chem. Int. Ed. 2001, 40, 1433. (b) Aggarwal, V. K.; Ferrara, M.; O'Brien, C. J.; Thompson, A.; Jones, R. V. H.; Fieldhouse, R. J. Chem. Soc., Perkin Trans. 1 2001, 1635. (c) Aggarwal, V. K.; Alonso, E.; Ferrara, M.; Spey, S. E. J. Org. Chem. 2002, 67, 2335. 
10. (a) Antilla, J. C.; Wulff, W. D. J. Am. Chem. Soc. 1999, 121, 5099. (b) Antilla, J. C.; Wulff, W. D. Angew. Chem., Int. Ed. 2000, 39, 4518. (c) Yu, S.; Rabalakos, C.; Mitchell, W. D.; Wulff, W. D. Org. Lett. 2005, 7, 367.

11. Loncaric, C.; Wulff, W. D. Org. Lett. 2001, 3, 3675.

12. Wipf, P.; Jung, J.-K. J. Org. Chem. 2000, 65, 6319.

13. (a) Kelly, T. R.; Whiting, A.; Chandrakumar, N. S. J. Am. Chem. Soc. 1986, 108, 3510. (b) Maruoka, K.; Sakuarai, M.; Fujiwara, J.; Yamamoto, H. Tetrahedron Lett. 1986, 27, 4895. (c) Larsen, D. S.; O'Shea, M. D.; Brooker, S. Chem. Commun. 1996, 203.

14. Reviews: (a) Kocovsky, P.; Vyskocil, S.; Smrcina, M. Chem. Rev. 2003, 103, 3213. (b) Brunel, J. M. Chem. Rev. 2005, 105, 857.

15. Steroidal binaphthols were kindly provided by the Process Research Group, Schering AG, Berlin, Germany.

16. Schneider, M. F.; Harre, M.; Pieper, C. Tetrahedron Lett. 2002, 43, 8751.

17. Typical procedure: To a flame-dried Schlenk flask cooled under argon was added a solution of ligand $(0.051 \mathrm{mmol})$ and triphenylborate $(0.15 \mathrm{mmol})$ in methylene chloride $(2.0 \mathrm{~mL})$. The reaction mixture was heated at $55{ }^{\circ} \mathrm{C}$ for $1 \mathrm{~h}$ under an atmosphere of argon. Vacuum was then applied for 30 min while heating was continued. The dried catalyst was cooled to room temperature under argon and dissolved in toluene $(430 \mu \mathrm{L})$. The solution was transferred via syringe to a flame-dried flask under argon at room temperature. A solution of imine $(0.51 \mathrm{mmol})$ in toluene $(430 \mu \mathrm{L})$ was added by syringe to the catalyst solution, and the reaction mixture was stirred for $10 \mathrm{~min}$, treated with ethyl diazoacetate $(59 \mu \mathrm{L})$, and stirred at room temperature for $18 \mathrm{~h}$. The mixture was then diluted with methylene chloride and concentrated in vacuo to a lime-green solid. Chromatography on $\mathrm{SiO}_{2}$ (hexanes $/ \mathrm{CH}_{2} \mathrm{Cl}_{2}$ 2:1.5) gave a white solid. (2S,3S)-Ethyl 1-benzhydryl-3-(4-bromophenyl)aziridine-2carboxylate (13) was obtained in 76\% and in 78\% ee in a cis:trans ratio of 99:1: Chiral HPLC (Chiralcel OD); $\mathrm{t}_{\mathrm{r}}=6.29 \mathrm{~min}$ (major isomer) and $\mathrm{t}_{\mathrm{r}}=10.63 \mathrm{~min}$ (minor isomer); ${ }^{1} \mathrm{H}$ NMR $\delta 7.58$ (d, 2 H, $J=7.1 \mathrm{~Hz}$ ), 7.46 (d, $2 \mathrm{H}, J=7.0 \mathrm{~Hz}$ ), $7.19-7.40$ (m, $10 \mathrm{H}$ ), 3.95 (s, 1 H), 3.96 (q, 2 H, $J=7.1 \mathrm{~Hz}$ ), 3.15 (d, $1 \mathrm{H}, J=6.8 \mathrm{~Hz}$ ), 2.69 (d, $1 \mathrm{H}, J=6.8 \mathrm{~Hz}), 1.03$ (t, 3 $\mathrm{H}, J=7.1 \mathrm{~Hz})$.

18. Chiral HPLC (Chiralcel OD); $\mathrm{t}_{\mathrm{r}}=7.75 \mathrm{~min}$ (major isomer) and $\mathrm{t}_{\mathrm{r}}=15.11$ (minor isomer); Mp 119-121 ${ }^{\circ} \mathrm{C}$ (Hexanes/CH $\mathrm{Cl}_{2}$ ); $[\alpha]_{\mathrm{D}}-13.3$ (c 2.1, $\mathrm{CH}_{2} \mathrm{Cl}_{2}$ ); ${ }^{1} \mathrm{H}$ NMR $\delta 7.63$ (d, $2 \mathrm{H}, J=$ $7.6 \mathrm{~Hz}$ ), 7.51 (d, $2 \mathrm{H}, J=7.6 \mathrm{~Hz}), 7.21-7.39$ (m, $5 \mathrm{H}), 6.98$ (s, $1 \mathrm{H}), 6.89$ (d, $1 \mathrm{H}, J=8.0$ $\mathrm{Hz}$ ), 6.72 (d, $1 \mathrm{H}, J=8.0 \mathrm{~Hz}$ ), 5.90 (s, $2 \mathrm{H}), 4.03$ (q, $2 \mathrm{H}, J=7.1 \mathrm{~Hz}), 3.96$ (s, $1 \mathrm{H}), 3.18$ (d, $1 \mathrm{H}, J=6.8 \mathrm{~Hz}), 2,66(\mathrm{~d}, 1 \mathrm{H}, J=6.8 \mathrm{~Hz}), 1.10(\mathrm{t}, 3 \mathrm{H}, J=7.1 \mathrm{~Hz}) ;{ }^{13} \mathrm{C} \mathrm{NMR} \delta 167.7$, 147.1, 146.8, 142.4, 142.3, 128.9, 128.4, 127.5, 127.4, 127.2, 121.1, 108.3, 107.6, 100.8, 77.6, 60.5, 47.9, 46.4, 14.0; MS (EI) (rel intensity) 401 ( $\left.\mathrm{M}^{+}, 1.8\right), 234$ (100), 161 (98), 152 (28), 76 (33); HRMS (EI) calcd for $\mathrm{C}_{25} \mathrm{H}_{23} \mathrm{NO}_{4} 401.1627$, found 401.1641.

19. Chiral HPLC ((Chiralcel OD; hexanes/2-propanol $=7.5: 2.5) \mathrm{t}_{\mathrm{r}}=10.6$ (major isomer), $\mathrm{t}_{\mathrm{r}}=$ 12.61 (minor isomer); $\mathrm{Mp} 55-57{ }^{\circ} \mathrm{C}$; $[\alpha]_{\mathrm{D}}-7.9$ (c 2.4, $\mathrm{CH}_{2} \mathrm{Cl}_{2}$ ); ${ }^{1} \mathrm{H}$ NMR $\delta 7.98$ (dd, $1 \mathrm{H}, J=$ 1.1, 7.9 Hz), 7.63-7.83 (m, $3 \mathrm{H}$ ), 7.55 (d, 2H, $J=7.1 \mathrm{~Hz}$ ), 7.44 (d, $2 \mathrm{H}, J=6.9 \mathrm{~Hz}$ ), 7.15- 
7.38 (m, 8 H), 7.02 (dd, $1 \mathrm{H}, J=1.1,8.0 \mathrm{~Hz}$ ), 3.97 (s, $1 \mathrm{H}$ ), 3.96 (q, $2 \mathrm{H}, J=7.0 \mathrm{~Hz}$ ), 3.49 (d, $1 \mathrm{H}, J=6.7 \mathrm{~Hz}$ ), $2.70(\mathrm{~d}, 1 \mathrm{H}, J=6.7 \mathrm{~Hz}), 1.02(\mathrm{t}, 3 \mathrm{H}, J=7.1 \mathrm{~Hz}) ;{ }^{13} \mathrm{C}$ NMR $\delta 167.5$, 148.6, 148.0, 142.3, 142.2, 135.3, 132.0, 131.8, 131.0, 129.1, 128.9, 128.5, 128.3, 127.7, 127.6, 127.2, 127.1, 127.0, 124.8, 121.3, 77.6, 60.6, 46.2, 43.7, 13.9; MS (EI) (rel intensity) 557 ([M-1] $]^{+}, 0.3$ ), 485 ([M-CO $\left._{2} \mathrm{Et}\right]^{+}$1.3), 391 (93), 186 (57), 167 (100), 132 (76), 121 (91); HRMS (EI) calcd for $\mathrm{C}_{27} \mathrm{H}_{21} \mathrm{~N}_{2} \mathrm{O}_{5} \mathrm{~S}_{1}$ (M-CO $\mathrm{CO}_{2} \mathrm{Et}$ ) 485.1171, found 485.1163. 